This is the peer reviewed version of the following article:

Aiello, V, Reverberi, PM, Brasili, C. "European identity and citizens' support for the EU: testing the utilitarian approach" Reg Sci Policy Pract. 2019

which has been published in final form at

https://doi.org/10.1111/rsp3.12242

This article may be used for non-commercial purposes in accordance with Wiley Terms and Conditions for Use of Self-Archived Versions. 


\title{
European identity and citizens' support for the EU: testing the utilitarian
}

\section{approach}

\begin{abstract}
Despite Cohesion Policy represents one-third of the EU budget, research on the role of EU Cohesion Policy in promoting the European identity is still scarce. Taking stock of a new dataset of citizens' support for and identification with the EU identity at the regional level, we aim to answer to the following questions: what are the determinants of support and identification with EU? Do EU fiscal transfers affect public support for the EU and the European identity? Do citizens' awareness about the Cohesion Policy play a role in it? We find that attitudes towards the EU are driven by individuals' perceptions of the economy in their region and of the effectiveness of EU institutions in solving the regional problems. We don't find evidence of a Cohesion Policy effect, but it provides useful indications for further research.
\end{abstract}

\section{Introduction}

The Cohesion Policy (CP) has recently turned thirty. However, this anniversary comes at a difficult time for Europe-enthusiasts. Recent national elections in the Member States showed a growing popularity of Euroskeptic parties and low trust towards the European institutions. Growing UK citizens' anti-EU positions has been followed by yet less harmless but similarly threatening political patterns in Poland, France, Germany and Italy.

The roots of this trend can be traced back to the 2008 financial crisis and the economic distress that followed it. This contributed to widening the gap between winners and losers of the globalization process (Braun and Tausendpfund, 2014; Serricchio et al., 2013). As a champion of the benefits brought by market integration and the free movement of people and capital, the European Union (EU) became the main target of the growing political discontent that populist parties fuelled in particular in the most vulnerable segments of society. The $\mathrm{CP}$, an investment policy with redistributive objectives, proved to be little effective in smoothing discontent, due to the financial endowments and the way the policy is designed and implemented.

These trends have highlighted the attention on the mechanisms behind the construction of a sense of European identity among EU citizens and their support for the EU. As pointed out by Habermas (2012) and Risse (2014), the identification of individuals with other European citizens and 
the trust towards other Europeans are preconditions for the establishment of a European community and the legitimization of the process of European integration. Identification with and support for the EU have built on the EU capacity to promote national economic welfares (Eichenberg and Dalton, 1993). This commitment was reinforced through the Europe 2020 Strategy for a smart, sustainable and inclusive growth.

This paper offers an empirical assessment of the mechanisms for the development of individuals' support for both the EU integration and identification as they have been advanced by the utilitarian theory and tests for the existence of a Cohesion Policy effect. Among the approaches available for analysing the European identity, we focus on the instrumental rationality approach, according to which people who view EU membership as a sustained source of personal or territorial benefit may develop a higher intensity of attachment to Europe. «The presumption is that citizens evaluate the economic consequences of European integration for themselves and for the groups of which they are part, and that such consequences motivate their attitudes» (Marks and Hooghe, 2005:420).

The utilitarian approach has received considerable attention by scholars of European integration (Cram, 2012; Gabel and Palmer, 1995; McLaren, 2004), but only a few studies have also tested this perspective with respect to the development of identity (Verhaegen et al., 2014).

This paper aims to contribute to this debate by shedding light on the mechanisms behind citizens' attitudes towards the EU and to assess the contribution of $\mathrm{CP}$ in influencing their support for the EU and their sense of feeling European. Our paper brings two main contributions to the literature: first, it exploits a novel dataset on citizens' support for and identification with the EU and on the European Structural and Investment Funds (ESIF) payments and expenditure; second, it is one of first studies $^{1}$ that adopts a regional perspective.

This allows to take into account the spatial emphasis that has recently characterized academic and political debates over the CP and the EU in general. From a place-based approach to territorial development (see Barca, 2009), regional/separatist movements and rhetoric used in opposition to central authorities ${ }^{2}$ emerged. It also allows to account for the recent dynamics of territorial inequalities across the EU, where the between-country component decreased while the within-country one increased (Muštra and Škrabic, 2014; Vacas-Soriano and Fernández-Macías, 2018).

\footnotetext{
${ }^{1}$ Borz et al. (2018) investigated the impact of EU Cohesion Policy on citizens'identification with Europe in 17 regions from 12 Member states.

${ }^{2}$ See Catalonia's referendum for independence (1 October 2017), but also the requests for higher decentralization recently put forward by the Italian regions of Lombardy, Emilia-Romagna and Veneto (see, among others, Viesti (2019), Grazzini et al. (2019))
} 
The paper is organized as follows: Section 2 presents the theoretical framework, which discusses the concepts of support and identification, the economic utilitarian approach as well as the other main perspectives offered by extant literature; Section 3 presents the data and the statistical model used to empirically test the three hypotheses of this paper; Sections 4 shows and comments the results of the empirical analysis in the different steps it has been carried out; Section 5 provides final remarks and policy recommendations feeding the ongoing debate around the post-2020 CP framework.

\section{Theoretical framework}

Support to (the integration of) the EU and European identity are distinct yet partially overlapping concepts.

An extensive review of the different conceptualizations of support is offered by Loveless and Rohrschneider (2011), which also show the different ways support has been operationalized in surveys and public opinion analyses. Here we consider support to the European integration as a positive attitude towards a closer cooperation between European member states (Eichenberg and Dalton, 1993).

The concepts of identity and identification with the EU have been analysed in the literature in terms of individual and collective European identity. Individuals' identification can be explained as «citizens' self-categorisation as European together with their evaluations of their membership in the European collective and their affective attachment to Europe and other Europeans» (Bergbauer, 2018, p.6). Bergabuer's definition is grounded on Tajfel's work in the social psychology field (Tajfel, 1981). Her conceptualization of individual identification includes a cognitive, an evaluative and an affective dimension, which focus respectively on the individual's self-categorization (awareness) as a member of a group, the negative or positive value connotation assigned to it and the emotional attachment (the we-feeling).

The cognitive and evaluative dimensions are at the core of the concept of collective identity as defined by the social psychology approach (David and Bar-Tal, 2009), while the we-feeling or sense of community lies at the root of the sociological perspective towards collective identity put forward by Easton (1965). Bergbauer (2018) combines the two approaches by offering the following normative definition of European identity: «A collective European identity will be stronger, the higher the number of EU citizens who identify with Europe, the stronger citizens' identification with Europe, and the more citizens are aware of other citizens' identification with Europe» (Bergbauer, 2018, p. 25). As highlighted by Jiménez et al. (2004), in contrast to historically rooted national identities, European identity is primarily instrumental, in so far, it is at least partially influenced by 
the citizens' perception of the benefits they get from EU integration. European identity is thus more contingent and yet more stable compared to support for the EU integration, which can fluctuate with the change in public opinion, as shown by Van Ingelgom (2014).

Therefore, Bergbauer (2018) affirmed that European identification differs conceptually and empirically from EU support. While identification with Europe shows citizens' self-categorisation as European and their affective attachment to Europe and other Europeans, the EU support refers to positive orientations towards the EU institutions and/or further steps in EU integration. Given the economic motivations underpinning the construction of the EU, the main theoretical framework for explaining the development of the support for EU integration and EU identity adopts an economic utilitarian approach. According to the utilitarian model of public support by Gabel and Palmer (1995), EU citizens in different socioeconomic contexts have different experiences of the costs and benefits associated with an integrative policy. In this approach, citizens are rational actors who are more (less) supportive of the European integration the more (less) they reap its benefits and avoid its costs. In other words, support for the EU is positively related to the citizens' gains of integration.

However, the drivers of intervention in a rational calculation approach can differ. According to Hooghe and Marks (2005), one can distinguish at least two points of view: an egocentric and a sociotropic one. The egocentric point of view (Gabel and Palmer, 1995) claims that EU citizens' support for European integration is mediated by their microeconomic considerations and positions regarding market liberalization. On the other hand, the sociotropic point of view puts more emphasis on the macro-scale. Both perspectives allow for an additional distinction: support for EU integration or/and EU identity can be shaped by both objective and subjective factors.

On one hand, from an egocentric - objective point of view, wealthy citizens can benefit from capital liberalization, thus exploiting the greater investment opportunities provided by the European Single Market, while citizens with low income could see their welfare being reduced as liberalization makes it less costly for capital to move rather than to accede to labour demands, thus making them less supportive of the European integration (Gabel, 1998). On the other hand, from an egocentric subjective point of view, the individual perception of having, or not, benefited from an EU project can increase, or decrease, the level of support for EU integration or/and EU identity. The sociotropic - objective point of view advocates that individual's support depends on the individual evaluation of national economic conditions - as proxied by the GDP growth, unemployment or the inflation rate and that residents of countries that are net recipients of the EU spending are more likely to support European integration compared to those from donor countries (Anderson and Reichert, 1995; Brinegar et al., 2004; Diez Medrano, 2003; Hooghe and Marks, 2005). 
Beyond objective factors, subjective economic evaluations can also intervene. Citizens who feel confident about the economic future are more likely to look at the European integration in a positive way, whereas those who are fearful may lean towards Euro-scepticism and their attitudes may be more sensitive to group identities (Hooghe and Marks, 2005).

Knowledge and information are two important factors. Levy and Phan (2014) showed that citizens tend to be generally uninformed about EU policies and the real economy, which makes it unlikely that an individual's support be determined on the basis of objective economic measures. As a consequence, any utilitarian consideration will be made on the basis of citizens' perception of the surrounding world.

This theory is corroborated by empirical evidence, as scholars have found that objective national economic conditions influence citizens' support for EU integration only to a limited extent (Gabel and Whitten, 1997), and that perceived costs and benefits are what largely drive the attitudes of both sociotropic and egocentric individuals. Verhaegen et al. (2014) show that the economic utilitarianism hypothesis holds true also for the identity formation, although to a weaker extent compared to support for integration. In addition, it confirms that perceptions about benefits contribute more than objective economic indicators do.

Most of the empirical works are at the national level. In our opinion, this has the effect of limiting the scope of the investigation of the role of one of EU's most relevant policy, CP, which has a mainly regional dimension. Initially conceived as an investment policy aimed at fostering economic growth in less developed regions, CP has eventually become the flag of a European way of policymaking able to shape national and local contexts, on both a political and economic level. Capello and Perucca (2017) identify four reasons why CP is a vehicle for the development of European identity: i) it exerts a daily life impact by helping national and local governments address regional needs; ii) with a total budget of about 350 billion euro both in the 2007-2013 and in the 20142020 programming periods, the CP represents to one-third of the EU total budget and has the second largest share of resources after the Common Agricultural Policy; iii) the implementation of the CP is carried out at regional level, in compliance with the multi-level governance system and the partnership principle which aim at increasing the policy's legitimacy through the involvement of local authorities and populations; iv) the largest part of resources targets "convergence" regions in order to help them catch up with richer ones, thus conveying a sense of solidarity and community among different territories.

The previous studies on the relationship between structural funds and support for European integration show conflicting results. A study by Duch and Taylor (1997), using regional allocation data in 1983 and 1986, found that CP funding transfers do not affect positively public support for the 
EU. Osterloh (2011), in contrast, finds that an increase of per capita transfers by 100 Euro increases the probability of being supportive of the EU of approximately 5 to $15 \%$ and that a relevant role in this relationship is played by awareness. This, in turn, is highly dependent on individual characteristics, such as education, and the information source through which it is generated. Verhaegen et al. (2014) found that EU funds have a negative relationship with support for EU integration. According to Chalmers and Dellmuth (2015), this is due to the fact that the relationship between transfers and support to integration is mediated by three mediating factors of financial gains derived from the ESIF: (i) a positive predisposition to European integration, (ii) the capacity to receive and interpret signals of economic solidarity, and (iii) political parties' stance on supranational redistribution.

Fewer works are available on the relationship between EU transfers and identity. Borz et al. (2018) provide evidence of the positive impact of CP on European identity. Scheuer and Schmitt (2009) theorize that higher levels of European identity in the Southern countries might be due to the higher flow of structural funds, while the empirical analysis run by Verhaegen et al. (2014) returns no statistical significance for the relationship between structural funds and identity.

An explanation for that is offered by Capello and Perucca $(2017,2019)$, who show that only when the targets of the policy match the individuals' (perceived) needs does the impact of CP on the citizens' identity become positive and statistically significant. A precondition for this to happen is that citizens be aware of the policy. Yet, the visibility of CP is not to be taken for granted, as local political actors can deliberately hide the EU contribution for their own electoral purposes. Thus, the region's quality of institutions can play a role in this relationship, by increasing the levels of transparency and limiting opportunistic and corrupted behaviours in the use of EU funds.

These behaviours can undermine citizens' trust toward institutions, which is the crucial factor for developing European identity according to the institutionalist approach. Verhaegen et al. (2018) empirically show that trust towards institutions has a stronger relationship with European identity than trust towards other Europeans. This seems to put additional emphasis on the effectiveness and the visibility of the EU institutions and the way they are perceived by citizens.

Within the single utilitarian theoretical framework, multiple mechanisms can thus be distinguished which can contribute to the development of a pro- or anti-EU attitude as operationalized in terms of support and identification. The hypotheses that the empirical analysis carried out in the next section of the paper is going to test are then summarized as follows:

- Hp 1 - the sociotropic view: Support for the integration of the EU and European identity are influenced by the regional context in which citizens reside. However, 
objective measures of the region's economy (Hp 1a) exert a weaker impact on individuals' attitudes than people's perceptions of it ( $\mathrm{Hp} \mathrm{1b);}$

- Hp 2 - the egocentric view: Support and identity are influenced by the individuals' position within such a context and by their personal experiences with the effects of EU integration. This relationship is driven more by the benefits that individuals perceive to get from EU membership (Hp 2b) rather than by the practical advantages of living in the EU (Hp 2a);

- Hp 3 - the CP effect: CP transfers have a positive impact on European identity and support for EU integration.

Beyond hypotheses testing, the paper will also account for alternative mechanisms for the development of identity, i.e. awareness, attachment and evaluation as explained by the sociological perspective. Consequently, we expect individuals who are more informed about the EU, more prone to get involved in its political events and more appreciative of the way it works to be more supportive of the EU integration and to feel a higher sense of identity. According to Bergbauer (2018), European identification and EU support differs conceptually, in what they are, and empirically, in how they are measured. By using the same utilitarian framework, our analysis allows to identify similarities and differences between the two conceptualizations.

In the next section, a description of the data and the methodology used to assess these hypotheses is provided.

\section{Data and methodology}

\subsection{Models and sources of data}

We develop and run two regression models. One model relates to the support for EU integration; the other model to the European identification. The models are characterized by the same independent and control variables. With the aim to take into account the regional dimension ${ }^{3}$, we use a multilevel analysis estimated via the Maximum Likelihood method, where individuals represent the first level of analysis, while the regions are the second level.

In particular, we adopt two different model specifications based on the dependent variable analysed. As a measure of support for EU integration, we use the responses to the PERCEIVE survey question: "In general, do you think that (YOUR COUNTRY'S) EU membership is: a good thing (1),

\footnotetext{
${ }^{3}$ The regional aggregation in the survey is at NUTS 2 level for all of the countries, except for Germany, UK and Sweden (level of aggregation at NUTS 1), Latvija and Estonia (NUTS 0, the whole country).
} 
a bad thing (2), neither good nor bad (3), not sure (4)", widely used in literature to measure support for EU integration. We recoded this variable into a dummy variable equal to 1 if the respondent thinks that its country's EU membership is a good thing, and 0 otherwise. For support for EU integration, we employ a two-level logistic regression model with random intercept at the regional level (1).

$$
\log \left(\frac{\pi_{i r}}{1-\pi_{i r}}\right)=\left(\beta_{0}+\zeta_{r}\right)+\Sigma_{k=1}^{K} \beta_{k} x_{k i r}
$$

Where $\pi_{i r}$ is the probability that individual $i$ in region $r$ thinks that its country's EU membership is a good thing, $\log \left(\frac{\pi_{i r}}{1-\pi_{i r}}\right)$ is the log-odds that the outcome variable for individual $i$ in region $r$ is $1,\left(\beta_{0}+\zeta_{r}\right)$ is the intercept for a given region $r$ with $\zeta_{r} \sim \mathrm{N}\left(0, \sigma_{u}^{2}\right)$, and $x_{k i r}$ are covariates (which include individual and context variables).

With respect to European identity, we use a linear approximation for the dependent variable (measured on a scale ranging from 0 to 10) and a multiple linear regression model. In order to account for the correlation among individuals' responses in the same region, we use a linear random intercept model with covariates (2), which is a regression model with a regional specific intercept.

$$
y_{i r}=\left(\beta_{0}+\zeta_{r}\right)+\sum_{k=1}^{K} \beta_{k} x_{k i r}+u_{i r}
$$

Where $y_{i r}$ is the response variable for individual $i$ in region $r,\left(\beta_{0}+\zeta_{r}\right)$ is the regional specific intercept, $x_{k i r}$ are covariates and $u_{i r}$ is the error term specific for each individual ${ }^{4}$.

Following the debate in the literature, we use the responses to the PERCEIVE survey question: "People may feel different degrees of identity with their region, their country, or with Europe on whole, as measure of European identity. On a 0-10 scale, with ' 0 ' being 'I don't identify at all, and ' 10 ' being 'I identify very strongly', how strongly you identify yourself with Europe?'.

In order to measure European identity, many authors (Fligstein et al., 2012; Roose, 2013) make use of the Moreno question in the Eurobarometer: "In the near future, do you see yourself as (1) European only, (2) European and [nationality], (3) [nationality] and European, or (4) [nationality] only?". Moreover, the Eurobarometer proxies European identity by asking about the support to European integration or about the feeling to be European (Scheuer and Schmitt, 2009, Verhaegen et al., 2014). Several other works have used specific surveys to analyse particular aspects: self-esteem scale applied to European feelings (Agirdag et al., 2012), feeling European in one's day-to-day life and attachment to the EU (Verhaegen et al., 2018).

\footnotetext{
${ }^{4}$ For further details: Rabe-Hesketh and Skrondal (2012)
} 
The data used to examine the explanatory power of our hypotheses come from different sources (Aiello, Reverberi, Brasili, 2019): the PERCEIVE ${ }^{5}$ Survey, EUROSTAT and a dataset on EU funding provided by the European Commission's Directorate-General for Regional and Urban Policy (DG Regio). The PERCEIVE survey collects information from a sample of 17,147 individuals of 18 years of age or older from 15 EU member states. Countries were selected on the basis of variation in terms of geography, size and institutional quality. Their population represents over $85 \%$ of the EU population. Its design and results are described in Bauhr and Charron (2018). The survey includes questions that help to identify i) the respondents' awareness of EU Regional Policy; ii) their identification with Europe, their country or region, and European values; iii) their political attitudes and values. In addition, the survey includes measures for the respondents' support for $\mathrm{CP}$ and their demographic and socioeconomic characteristics. The survey provides both the dependent variables of the analysis (support for European integration and identification with Europe) and some variables used to proxy their determinants, i.e.: the respondents' socioeconomic status, their awareness of $\mathrm{CP}$, the evaluation on the effectiveness of $\mathrm{EU}$ at dealing with the biggest problem in their region and the opinion on the economic situation of their regions.

Tables A1 - A3 (in the Appendix) show the composition of the sample by country, the description of the variables and the summary statistics.

\subsection{Data operationalization}

As stated in Hp 1 and Hp 2, we expect support and identification to be related with a number of objective/subjective and regional/individual benefits which are included as covariates in the empirical analysis as follows.

Objective egocentric indicators are obtained from the PERCEIVE survey, and include the household income, the occupational status, the educational level and the years lived in the region.

To our knowledge, this is the first time that the variable "numbers of years lived in the region" is tested as a factor mediating the support to and the identification with the EU. We expect that as the years spent in the same region decrease, the level of support and identification increases, because people who have been living in the same region for a shorter time might have higher mobility propensity. This implies that they should be more willing to exploit the opportunities created by the common market, and they should thus be more in favour of the free movement of good and persons that comes with EU integration.

\footnotetext{
${ }^{5}$ H2020 - Reflective Society 2015 - PERCEIVE: Perception and Evaluation of Regional and Cohesion policies by Europeans and Identification with the Values of Europe. Grant agreement nr. 693529.
} 
As subjective egocentric indicator we use the responses to the PERCEIVE survey question: "To your knowledge, have you ever benefited in your daily life from any project funded by the EU?". We code the variable equal to 1 if the respondent thinks to have benefited from any EU project and 0 otherwise. We expect that as the citizens' perception to be a direct or indirect beneficiary of Cohesion Policy increase, both support and identification increase, too. Clearly, this question involves two distinct aspects, in so far the perception over the benefits of EU policies implies the respondent to be aware about the existence of EU funded projects.

As objective sociotropic indicators that we can relate to the $\mathrm{CP}$ effect (Hp 3) we use the net contribution of the member states to the EU budget and the total Structural Funds per capita paid by the EU. We took the net contribution in 2016 because is the most recent year available before the PERCEIVE survey.

The subjective sociotropic perspective is accounted for through the PERCEIVE survey question: "Compared with ( 5 years ago), do you think the economy in your region is: Better, About the same, Worse".

The alternative explanations for citizens' support for European integration and identification with Europe are controlled for through the following variables built from the PERCEIVE survey. For the awareness theory we use the question: "Have you ever heard about the following EU policies? (EU CP; EU Regional Policy; EU Structural Funds; any EU funded project in your region or area)", codified as a dummy variable equal to 1 if the respondent knows at least one EU policy and equal to 0 if none is known. We expected a positive relationship in so far, more aware citizens are expected to be more supportive and to have stronger identity. For the attachment theory we use the variable "Vote in EU parliamentary elections", where we expect a positive relationship between the number of times the respondent has voted for the elections of the European Parliament and both support and identification. For the evaluation theory we use the question: "How effective do you think the EU will be at dealing with the biggest problem in your region?", where support and identification are expected to positively relate with perceptions of EU effectiveness. The problem cited in the question refers to the biggest regional problem as perceived by citizens.

Following previous studies in the literature, we introduce as regional control variables: the GDP growth rate (2013-2016), the unemployment rate (2017) and quality of institutions ${ }^{6}$. The time of accession to the EU and a dummy variable for the Euro currency are included as control variables, too. Finally, age and gender are included as individual control variables, as we expect male and

\footnotetext{
${ }^{6}$ We proxied quality of institutions using the 2013 version of the 'European Quality of Government Index' (Charron et al. 2015).
} 
younger respondents to show higher support for European integration and higher identification (Fligstein, 2008).

\section{Results of the empirical analysis}

We start our analysis by showing some descriptive analysis of the dependent variables at the regional and country level. Figure 1 shows that the level of support for EU integration is differently distributed among the European regions. Since the survey took place one year after the Brexit referendum, the question concerning support for EU integration was not addressed by respondents in the United Kingdom, which implies that the UK is excluded from this analysis. The map shows that almost all ten European regions with the lowest average levels of support for EU integration are located in Italy. On the contrary, almost all ten European regions with the highest level of support for EU integration are based in Germany (NUTS 1) and Poland. Figure 2 shows that the levels of identification with Europe. Compared to support, the picture of regions' identification is less clear, as no strong national patterns can be detected within either high-ranked or low-ranked regions. The latter are located in Romania, Bulgaria, Italy, France and Netherlands, while the former are from Poland, Slovakia and Bulgaria.

[Figure 1 here]

[Figure 2 here]

From a country perspective (Figure 3), it can be noted that the Eastern countries Slovakia and Poland have in average the highest levels of identification, while Italy and the Netherlands, whose citizens are also the least supportive of EU integration of the whole sample, show lower levels of identification than the United Kingdom. Germany, Poland and Romania show the highest levels of support for European integration. In particular, the first two countries also rank among the highest positions in terms of identification with Europe. However, these are the only similarities that we can detect, and the lack of additional correspondence between the two pictures can be seen as a sign of the conceptual differences between support and identification.

[Figure 3 here] 


\subsection{Support}

The results of the two-level logistic regression model used to test support for EU integration are provided in Table 1.

The intraclass correlation coefficient (ICC) of Model I, which includes no covariates, supports the choice to employ a regional multilevel model, as it shows that $11 \%$ of the difference in the individuals' support to European integration is located at regional level. When we include a number of individual and regional control variables (Model II), the ICC decreases to almost $5 \%$.

All the control variables included in Model II are significant, except for unemployment. The newest Member States of the European Union are more likely to support European integration than respondents from the original six Member States. The GDP growth rate is positively linked to the support. Membership of the Eurozone shows the expected positive sign. Finally, the perceived level of institutional quality at the regional level (EQI), as expected, is positively associated with support for the EU.

In Model III, we include variables linked to the utilitarian theory, while taking into account the four previously seen perspectives. Regarding the egocentric-objective perspective, our results confirm previous works in this field. Indeed, the level of education and the type of employment are both strong predictors of the individuals' level of support. Students tend to be more supportive of the European project while unemployed people do not, and support grows as the level of education increases. As expected, support is higher for individuals with higher levels of income. The fewer the years an individual has lived in the same region, the higher the support for Europe is. This result supports the idea that those who were able to profit from the opportunities of the single market and the free movement of people are more supportive of the EU project, and the view that personal experiences are relevant in the individuals' assessment about the EU.

This is also confirmed when looking at the egocentric-subjective perspective: those who believe to have never benefited from an EU project or do not know if they have, show less EU support than those who believe or know they have ("Benefited from EU project").

While all the egocentric indicators of the utilitarian theory show the expected sign and statistical significance, the picture is different for the sociotropic indicators and to the CP effect. The amount of Structural Funds per capita allocated in the regions is not significant, while the region's membership in a net contributing State of the EU is significant but not relevant, in magnitude, in determining support to the EU project. As regards the sociotropic-subjective dimension, the perception of the economic trend of the region over the last 5 years, instead, is particularly relevant and of the expected negative sign. 
On the one hand, the non-significance of the Structural Funds per capita allocation emphasizes the greater importance of subjective and individual indicators in determining the support for the EU. On the other hand, these findings are in line with the controversial findings summarized in Section 2.

This result, combined with the result of the indicators at individual level, shows that perceptions of the personal and regional situation are important determinants of the individuals' support to EU integration.

By adding the individual indicators related to alternative theories (Model IV), these predictors remain significant. This shows that the utilitarian hypothesis is robust to accounting for other mechanisms in determining individuals' support to EU integration. The relationship between awareness of CP and support is positive, while the positive signs of the other variables support the "attachment" theory. In particular, those who voted both times in the last two elections of the European Parliament show greater support to the EU, like those who judge the effectiveness of the EU in solving the main problems perceived by the population at regional level.

[Table 1 here]

\subsection{Identification}

The same theoretical framework has also been applied to the phenomenon of identification with Europe. The results of the analyses (Table 2) are very similar to what has already been seen for the support. The main differences are in the greater level of identification for women than for men, in the non-significance of the growth rate of GDP and institutional quality (EQI). As for support, the access period to the EU is significant also for the development of identity. However, while in model II the newest member states show the highest level of identification with Europe, in model III and IV, after including the indicators related to the utilitarian theory, the countries that joined between 1973 and 1995 show the higher level of identification.

These results are partially consistent with the findings by Verhaegen et al. (2014, p. 308): "Against our expectations, we find that respondents tend to have a stronger European identity in member states that have been part of the EU for a shorter period. This contradicts the claim of Thomas Risse (2010) that time matters for European identity. Therefore, the specific economic situation in 
the newest member states may cause lower levels of European identity, while the recent accession in itself might stimulate a sense of European identity." Our results are strongly in favour of both higher identification and support in non-founding member states. The indicators related to the utilitarian theory behave similarly to the specification with support as dependent variable. A major difference is in the significant and positive sign of the amount of the Structural Funds per capita, even if the intensity of their contribution in explaining the phenomenon is very low. All in all, the utilitarian theory remains valid after the inclusion of regional and individual indicators related to alternative theories for the development of identity.

For both our dependent variables, support and identification, we can state that the utilitarian theory is valid in explaining the two phenomena, but there is a substantial difference between objective and subjective variables. In fact, the levels of support for the European project and the degree of identification with Europe seem to be determined, to a greater extent, by the latter. It is, in fact, the awareness of having benefitted in first person from EU-funded projects and the perception of recent improvements in the regional economic situation that explain much of the individuals' levels of support and identification. These results are in line with the findings of Borz et al. (2018) and Royuela and López-Bazo (2019) that argue that the perceived economic benefits of CP contribute to strengthening European identity.

The non-significance of the amount of the Structural Funds per capita with respect to support, and the significance, but with a very low magnitude, with respect to identification, deserve further investigation. Rodriguez-Pose and Fratesi (2004) suggest that the way in which EU funds are spent affect regional development. In their analysis, only the EU funds linked to the local endowment of human capital and economic performance seems to have a positive impact on regional development from a medium-term perspective. In line with this approach, some authors (Chalmers and Dellmuth, 2015 , 2018) argue that it is not the amount of the Structural Funds per se' that influences the support, but it is rather the type of destination of the expenditure. This means the quality and not the quantity of the expenditure matters. This seems to be reflected in the importance, in both our analyses, of the variable related to the perceived effectiveness of the EU in solving the main problems of the region. In fact, in Hp 3 (the CP effect) we suggest that support and identification are positively linked to a good use of the Structural Funds in solving regional problems.

[Table 2 here] 


\section{Concluding remarks}

This paper aims to empirically test the mechanisms for the development of individuals' support for the EU integration and EU identity as they have been advanced by the utilitarian theory. We exploit two sources of data and use a regional approach that has yet to be proposed in this field of literature. Along with the sociotropic and the egocentric explanations, the paper analyses a CP effect for which CP might contribute to foster support to and identification with the European Union among beneficiary populations.

Citizens from new Member States, which have a positive budgetary balance with the EU and whose regions are among the first beneficiaries of $\mathrm{CP}$, do actually display higher support and identification. However, this result does not seem to relate with the amount of the Structural Funds expenditure. Thus, further research is needed. According to our empirical analysis, attitudes towards the EU are influenced by the regional economic context, by individual factors such as education, income and mobility experiences. To a higher extent, this is influenced by individuals' perceptions of the situation of their region's economy and effectiveness of EU institutions in solving the region's problems.

With respect to the hypotheses explicated in Section 2, results thus speak of a prevalence of the egocentric view (Hp2) over the sociotropic view (Hp 1), and highlight a clear effect of perception (Hp b) over objectivity (Hp a) in the development of both support and identity. This calls for additional emphasis and investigation over the role of communication and the construction of the public discourse over public affairs, by the media and the institutions themselves. Moreover, these results suggest that individuals are influenced by the awareness to be a direct or indirect beneficiary of the policy.

In a multilevel governance system, as in the case of $\mathrm{CP}$, the way in which authorities manage and implement the policy can affect citizens' support and identification with the EU. CP's effectiveness in solving regional problems is strongly dependent on the cooperation between European and local authorities, which in turn calls for higher flexibility in the design and in the implementation of the Operational Programmes. As a matter of fact, when individuals think of Europe, they usually do it from a local point of view: more flexibility is necessary to promote the bottom-up approach in the programming phase and to provide ad-hoc mechanisms for easier adjustments in the strategy due to dynamic challenges in the socio-economic context during the implementation phase (Aiello et al., 2019).

As far as Hp 3 is concerned, our analysis does not support the existence of a CP effect per se' but it provides useful indications for further research. Knowledge of CP is positively related to both 
support and identity, and so is the awareness of being a beneficiary of an EU-funded project. These results highlight the role of communication. If the EU really wants $\mathrm{CP}$ to be a vehicle of European values across its territories and its communities, it must increase its communication effort to let citizens be more informed and aware of this policy.

Following Dellmuth and Chalmers (2018) and Capello and Perucca (2019), we also believe that the impact of the ESIF on support might depends on the extent to which spending is consistent with the regional economic needs. A promising line of future research would be analysing the impact of the amount of the Structural Funds in the 2007-2013 programming period with regard to the specific objective needs of the region and as they are perceived by the population. This would allow to extend the results of these analyses and to assess size and nature of the prevalence of perception over objectivity in the development of personal attitudes towards the EU.

\section{ACKNOWLEDGEMENT}

The authors acknowledge the support from the European Union's Horizon 2020, Research and Innovation Program, under the PERCEIVE project, Perception and Evaluation of Regional and Cohesion policies by Europeans and Identification with the values of Europe, Grant Agreement number 693529. 


\section{References}

Agirdag O, Huyst P, Houtte MV (2012) Determinants of the Formation of a European Identity among Children: Individual- and School-Level Influences. Journal of Common Market Studies 50(2) 198213

Aiello V, Brasili C, Calia PP, Marino A (2019) PERCEIVE project - Deliverable D7.5 Policy Brief (1): Guidelines on Cohesion Policies Implementation, DOI 10.6092/unibo/amsacta/6197

Aiello V, Reverberi PM, Brasili C (2019) PERCEIVE. WP1. Cohesion Policy and identification with the European Union at citizen level in different European countries. Survey at citizen level. European identity and citizens' support for the EU. University of Bologna. http://doi.org/10.6092/unibo/amsacta/6219 [Dataset]

Anderson CJ, Reichert MS (1995) Economic Benefits and Support for Membership in the E.U.: A Cross-National Analysis. Journal of Public Policy 15(3), 231-249

Barca F (2009) Agenda for a Reformed Cohesion Policy

Bauhr M, Charron N (2018) What Do Citizens Think About Redistribution and Aid Within the EU? Description and Highlights of a Pan-European Citizen Survey on Public Support for Cohesion Policy (QoG Working Paper Series No. 2) Gothenburg: Quality of Government Institute

Bergbauer S (2018) Explaining European Identity Formation. Cham: Springer International Publishing

Borz G, Brandenburg H, Mendez C (2018) The Impact of EU Cohesion Policy on European identity: Results from the COHESIFY citizen survey. COHESIFY Research Paper 14. Glasgow: University of Strathclyde

Braun D, Tausendpfund M (2014) The Impact of the Euro Crisis on Citizen's Support for the European Union. Journal of European Integration 36 (3):231-45

Brinegar AP, Jolly SK (2005) Location, Location, Location: National Contextual Factors and Public Support for European Integration. European Union Politics 6(2) 155-180

Capello R, Perucca G (2017) Cohesion policy perceptions of EU citizens. The role of context conditions (Research paper) Politecnico di Milano

Capello R, Perucca G (2018) Understanding citizen perception of European Union Cohesion Policy: the role of the local context. Regional Studies 52(11) 1451-1463

Capello R, Perucca G (2019) Citizens' perception of Cohesion Policy: from theory to empirical evidence. Regional Studies, 1-11

Chalmers AW, Dellmuth LM (2015) Fiscal redistribution and public support for European integration. European Union Politics 16(3) 386-407

Cram L (2012) Does the EU Need a Navel? Implicit and Explicit Identification with the European Union. Journal of Common Market Studies 50(1) 71-86.

David O, Bar-Tal D (2009) A Sociopsychological Conception of Collective Identity: The Case of National Identity as an Example. Personality and Social Psychology Review 13(4) 354-379

Dellmuth LM, Chalmers AW (2018) All spending is not equal: European Union public spending, policy feedback and citizens' support for the EU. European Journal of Political Research 57(1) 323

Díez Medrano J (2003) Framing Europe: Attitudes to European Integration in Germany, Spain, and the United Kingdom. Princeton University Press. 
Duch R, Taylor M (1997) Economics and the Vulnerability of the Pan-European Institutions. Political Behavior 19(1) 65-80

Easton D (1965) A systems analysis of political life. Wiley.

Eichenberg RC, Dalton RJ (1993) Europeans and the European Community: The Dynamics of Public Support for European Integration. International Organization 47(4) 507-534

European Commission (2018) Historic EU payments by MS \& NUTS-2 region (Filters by country, period and fund). Available at: https://cohesiondata.ec.europa.eu/EU-Level/Historic-EU-paymentsby-MS-NUTS-2-region-Filters-b/2qa4-zm5t

Fligstein N (2008) Euroclash: the EU, European identity, and the future of Europe. Oxford; New York: Oxford University Press.

Fligstein N, Polyakova A, Sandholtz W (2012) European Integration, Nationalism and European Identity. Journal of Common Market Studies 50(s1) 106-122

Gabel M (1998) Public Support for European Integration: An Empirical Test of Five Theories. The Journal of Politics 60(2) 333-354

Gabel M, Palmer HD (1995) Understanding variation in public support for European integration. European Journal of Political Research 27(1), 3-19

Gabel M, Whitten GD (1997) Economic Conditions, Economic Perceptions, and Public Support for European Integration. Political Behavior 19(1) 81-96

Grazzini L, Lattaruolo P, Macchi M, Petretto A (2019) Asymmetric decentralization: some insights for the italian case, Nota 4/2019 dell'Osservatorio Regionale sul Federalismo Fiscale

Habermas J (2012) The Crisis of the European Union: A Response. Wiley

Harteveld E, Meer T van der, Vries CED (2013). In Europe we trust? Exploring three logics of trust in the European Union. European Union Politics 14(4) 542-565

Hobolt SB, de Vries CED (2016) Public Support for European Integration. Annual Review of Political Science 19(1) 413-432

Hooghe L, Marks G (2005). Calculation, Community and Cues: Public Opinion on European Integration. European Union Politics 6(4) 419-443

Jiménez RMA, Górniak JJ, Kandulla M, Kiss P, Kosic A (2004). European and National Identities in the Eu's Old and New Member States: Ethnic, Civic, Instrumental and Symbolic Components , Rochester, NY: Social Science Research Network

Kritzinger S (2005) European Identity Building from the Perspective of Efficiency. Comparative European Politics 3(1) 50-75

Levy N, Phan B (2014) The Utility of Identity: Explaining Support for the EU after the Crash. Polity 46(4) 562-590

Loveless M, Rohrschneider R (2011). Public perceptions of the EU as a system of governance. Living Rev. Euro. Gov. 6, 2

McLaren LM (2004) Opposition to European integration and fear of loss of national identity: Debunking a basic assumption regarding hostility to the integration project. European Journal of Political Research 43(6) 895-912

Muštra V, Škrabić B (2014) Regional Inequalities in the European Union and the Role of Institutions. Review of Urban \& Regional Development Studies 26(1), 20-39 
Osterloh S (2011) Can Regional Transfers Buy Public Support? Evidence from EU Structural Policy Working Papers 169, Oesterreichische Nationalbank (Austrian Central Bank)

Perceive Project (2019) Deliverable 7.5 - Guidelines on Cohesion Policy implementation. Available at: https://www.perceiveproject.eu/wp-content/uploads/2017/09/PERCEIVE-project_Policy-Brief_DELIVERABLE-7.5-GUIDELINES-ON-COHESION-POLICY-IMPLEMENTATION.pdf

Rabe-Hesketh S, Skrondal A (2012), Multilevel and longitudinal modeling using Stata Stata Press, College Station, Texas

Risse T (2010) A Community of Europeans? Cornell University Press

Risse T (2014) No Demos? Identities and Public Spheres in the Euro Crisis. Journal of Common Market Studies 52(6), 1207-1215

Rodriguez-Pose A, Fratesi U (2004) Between Development and Social Policies: The Impact of European Structural Funds in Objective 1 Regions. Regional Studies 38:1, 97-113

Roose J (2013) How European is European Identification? Comparing Continental Identification in Europe and Beyond. Journal of Common Market Studies 51(2) 281-297

RoyuelaV, López-Bazo E (2019) Understanding the process of creation of European identity- the role of Cohesion Policy. Investigaciones Regionales, forthcoming

Scheuer A, Schmitt H (2009. Dynamics in European Political Identity. Journal of European Integration 31(5) 551-568

Serricchio F, Tsakatika M, Quaglia L (2013) Euroscepticism and the Global Financial Crisis. Journal of Common Market Studies 51(1), 51-64Tajfel H (1981) Human groups and social categories: studies in social psychology. Cambridge, New York: Cambridge University Press

Vacas-Soriano C, Fernández-Macías E (2018) Income Inequality in the Great Recession from an EUwide Perspective ifo Institute - Leibniz Institute for Economic Research at the University of Munich, vol. 19(2), pages 09-18, July

Van Ingelgom V (2014) Integrating Indifference: A Comparative, Qualitative and Quantitative Approach to the Legitimacy of European Integration. Colchester: ECPR Press

Verhaegen S, Hooghe M, Quintelier E (2014. European Identity and Support for European Integration: A Matter of Perceived Economic Benefits? Kyklos 67(2), 295-314

Verhaegen S, Hooghe M, Quintelier E (2018). The effect of political trust and trust in European citizens on European identity - CORRIGENDUM. European Political Science Review 10(2) 323323

Viesti G (2019) Verso la secessione dei ricchi? Autonomie regionali e unità nazionale. Editori Laterza, Roma-Bari

WIIW (2016. The Consolidation of Financial Data 1989-2013 on payments to programmes, Available at: https://publications.europa.eu/en/publication-detail/-/publication/31c556d1-e394-11 e6-ad7c01aa75ed71a1/language-en/format-PDF/source-68135194 
Figure 1. Mean level of support for European integration

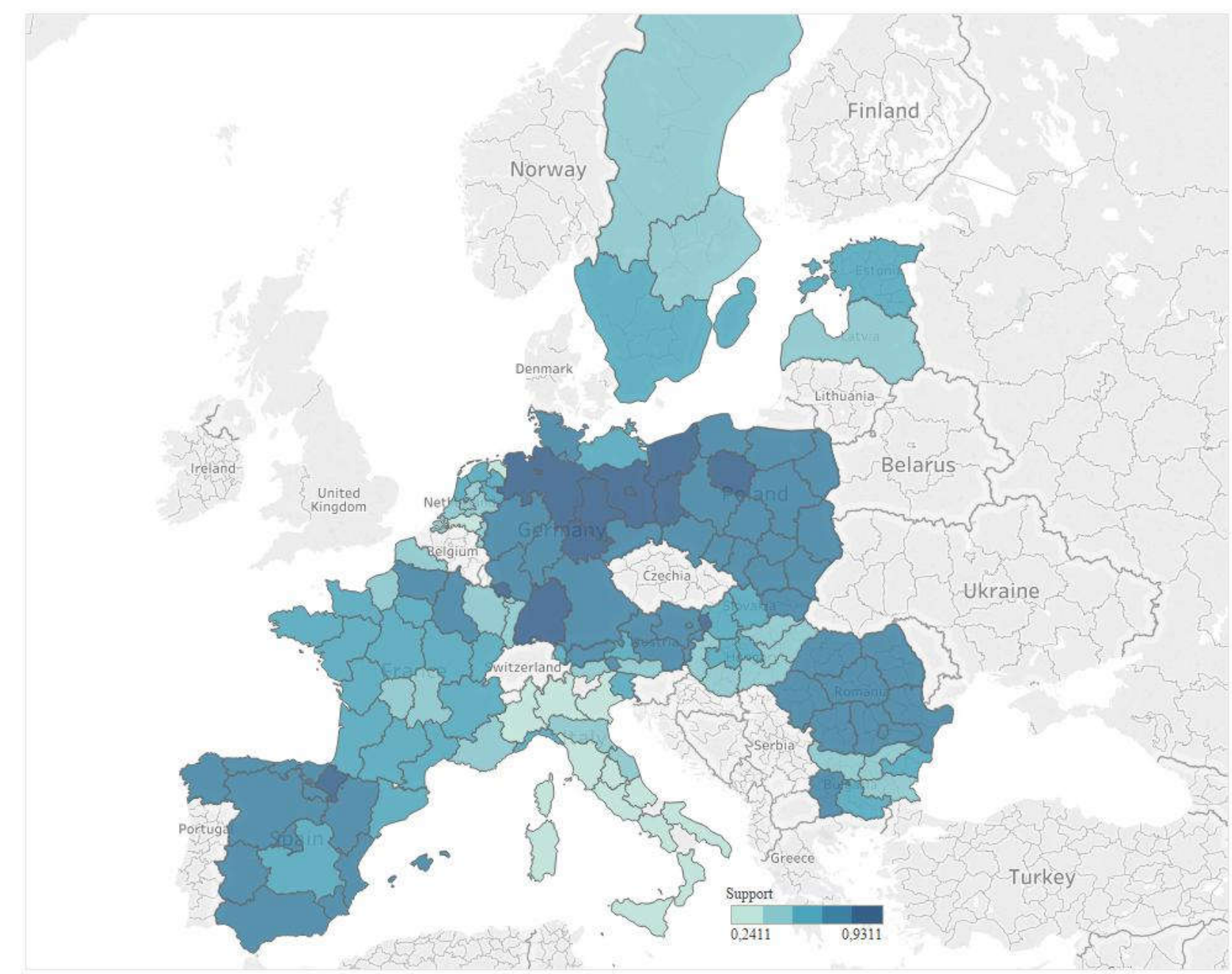

Source: Bauhr and Charron (2018)

Legend: Regional average value ( $\min 0-\max 1)$ 
Figure 2. Mean level of identification with Europe

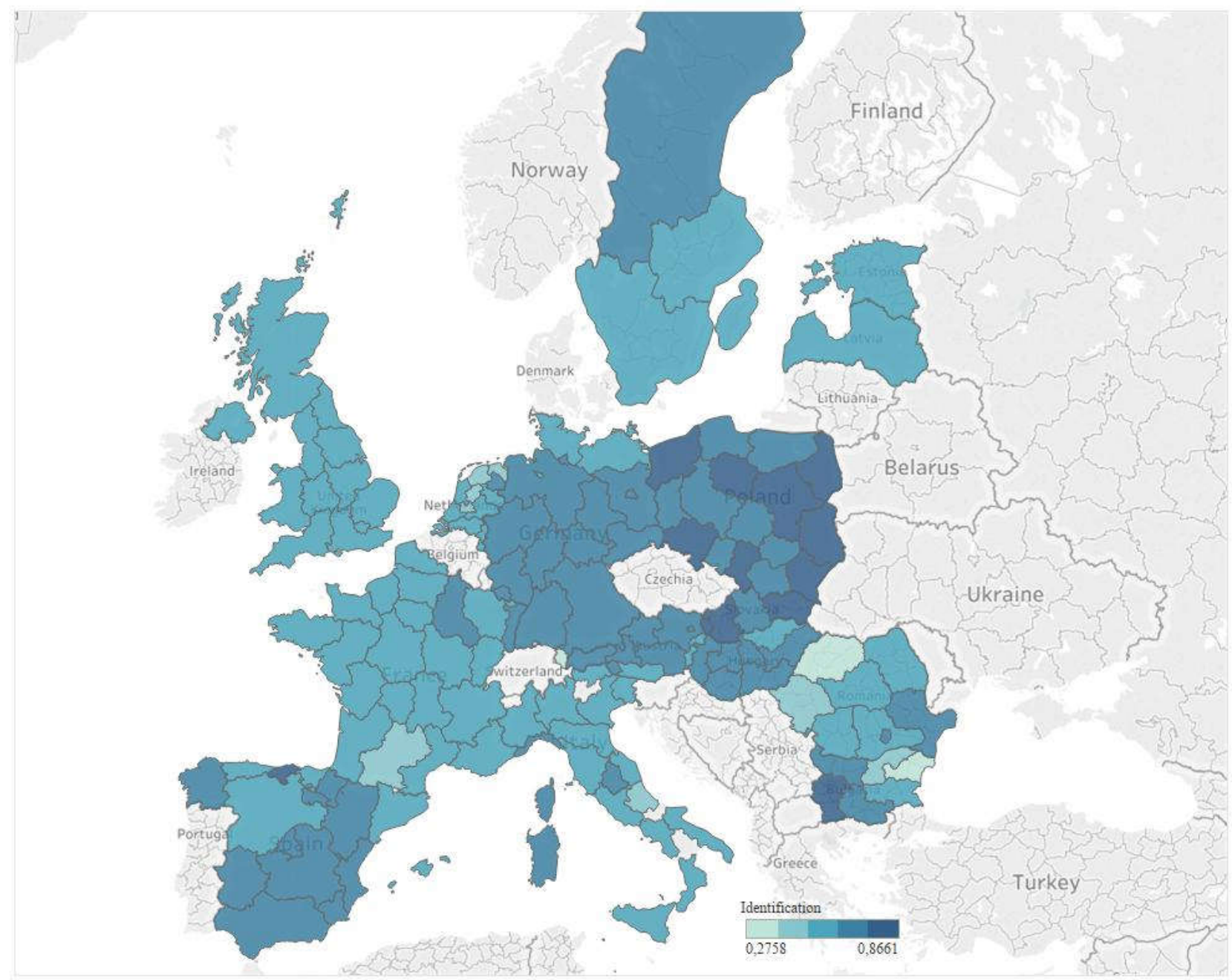

Source: Bauhr and Charron (2018)

Legend: Regional average value ( $\min 0-\max 1)$ 
Figure 3. Support for European integration and identification with Europe
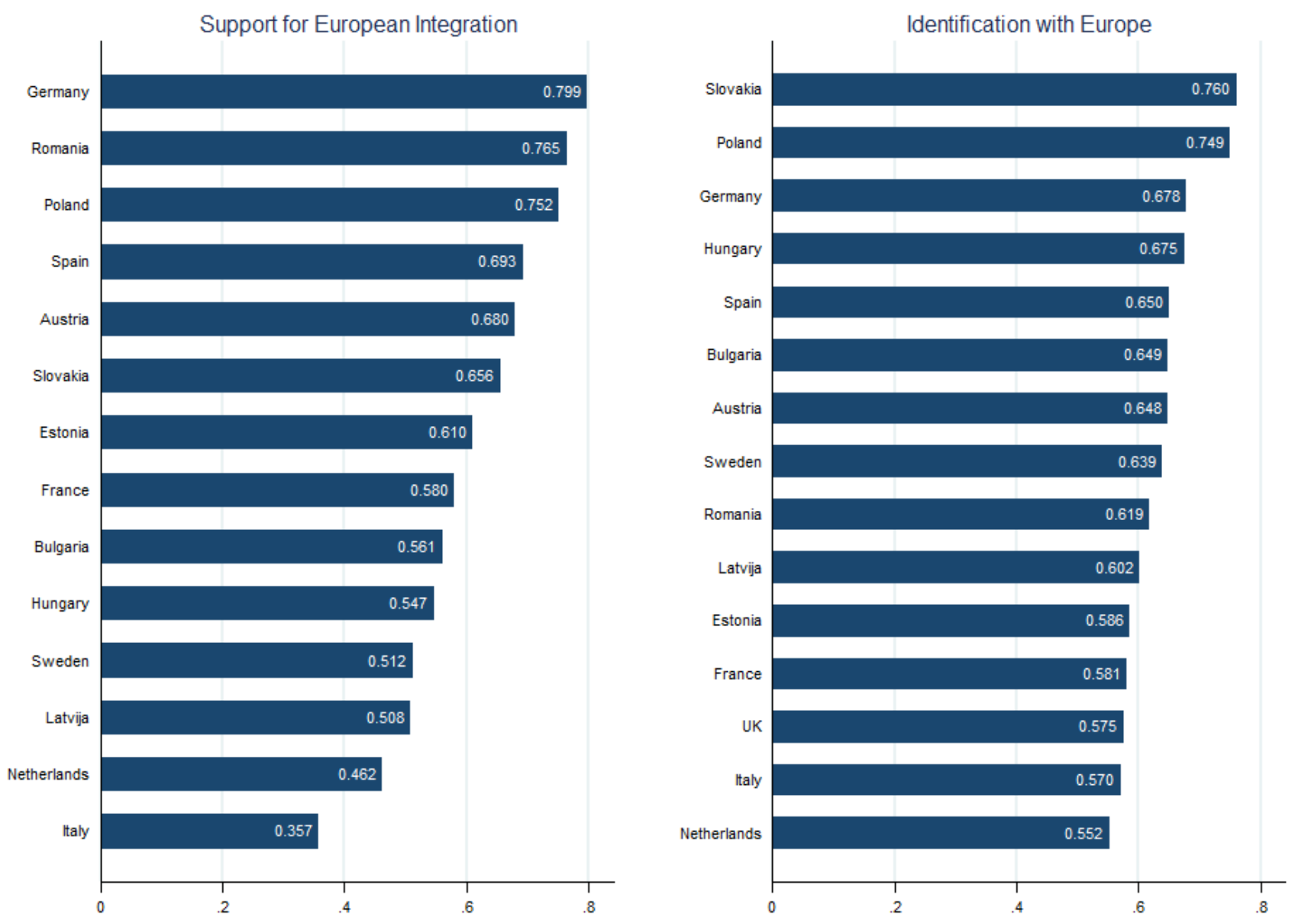

Source: Bauhr and Charron (2018)

Legend: Country average value 
Table 1. Two-level logistic regression for support for European Integration

\begin{tabular}{|c|c|c|c|c|c|c|c|c|}
\hline \multirow[b]{2}{*}{ Individual level controls } & \multicolumn{2}{|l|}{ Model I } & \multicolumn{2}{|l|}{ Model II } & \multicolumn{2}{|l|}{ Model III } & \multicolumn{2}{|l|}{ Model IV } \\
\hline & & & & & & & & \\
\hline Age & & & $0.006^{* * *}$ & $(0.002)$ & $0.016^{* * *}$ & $(0.002)$ & $0.012^{* * *}$ & $(0.003)$ \\
\hline Female & & & $-0.145^{* *}$ & $(0.045)$ & -0.060 & $(0.048)$ & -0.058 & $(0.049)$ \\
\hline \multicolumn{9}{|l|}{ Regional level controls } \\
\hline GDP growth & & & $0.045^{* * *}$ & $(0.011)$ & $0.041^{* * *}$ & $(0.011)$ & $0.024^{* *}$ & $(0.009)$ \\
\hline \multicolumn{9}{|l|}{ Accession (ref. 1957) } \\
\hline $1973-1995$ & & & $0.520^{* * *}$ & $(0.129)$ & $1.229^{* * *}$ & $(0.152)$ & $1.146^{* * *}$ & $(0.144)$ \\
\hline $2004-2013$ & & & $0.947^{* * *}$ & $(0.183)$ & $1.677^{* * *}$ & $(0.261)$ & $1.388^{* * *}$ & $(0.268)$ \\
\hline Unemployment & & & -0.012 & $(0.013)$ & 0.006 & $(0.012)$ & -0.009 & $(0.011)$ \\
\hline Eurozone & & & $0.965^{* * *}$ & $(0.104)$ & $1.131^{* * *}$ & $(0.101)$ & $1.078^{* * *}$ & $(0.099)$ \\
\hline EQI & & & $0.018^{* * *}$ & $(0.005)$ & 0.006 & $(0.004)$ & $0.009^{*}$ & $(0.003)$ \\
\hline \multicolumn{9}{|c|}{ Egocentric indicators (Utilitarian Theory) } \\
\hline \multicolumn{9}{|c|}{ Objective dimension } \\
\hline \multicolumn{9}{|l|}{ Occupation (ref. Employed) } \\
\hline Unemployed & & & & & $-0.315^{* * *}$ & $(0.088)$ & $-0.259^{* *}$ & $(0.089)$ \\
\hline Housewife & & & & & -0.079 & $(0.124)$ & -0.072 & $(0.129)$ \\
\hline Retired & & & & & -0.014 & $(0.074)$ & -0.013 & $(0.074)$ \\
\hline Student & & & & & $0.516^{* *}$ & $(0.174)$ & $0.555^{* *}$ & $(0.178)$ \\
\hline Other & & & & & 0.059 & $(0.154)$ & 0.037 & $(0.153)$ \\
\hline \multicolumn{9}{|l|}{$\begin{array}{l}\text { Education (ref: Elementary } \\
\text { school) }\end{array}$} \\
\hline High School & & & & & $0.341^{* * *}$ & $(0.061)$ & $0.288^{* * *}$ & $(0.065)$ \\
\hline Post-graduate & & & & & $0.836^{* * *}$ & $(0.101)$ & $0.747^{* * *}$ & $(0.107)$ \\
\hline Years in the area & & & & & $-0.004^{*}$ & $(0.002)$ & $-0.004^{* *}$ & $(0.002)$ \\
\hline \multicolumn{9}{|l|}{ Household income (ref. Low) } \\
\hline Medium & & & & & 0.103 & $(0.073)$ & 0.091 & $(0.076)$ \\
\hline High & & & & & $0.345^{* * *}$ & $(0.093)$ & $0.346^{* * *}$ & $(0.093)$ \\
\hline Don't know & & & & & $0.553^{* * *}$ & $(0.123)$ & $0.613^{* * *}$ & $(0.125)$ \\
\hline \multicolumn{9}{|l|}{ Subjective dimension } \\
\hline Benefited from EU project & & & & & $0.628^{* * *}$ & $(0.070)$ & $0.531^{* * *}$ & $(0.071)$ \\
\hline \multicolumn{9}{|c|}{ Sociotropic indicators (Utilitarian Theory) } \\
\hline \multicolumn{9}{|c|}{ Objective dimension } \\
\hline Structural Funds per capita & & & & & -0.000 & $(0.000)$ & 0.000 & $(0.000)$ \\
\hline Net Contribution & & & & & $0.000^{* * *}$ & $(0.000)$ & $0.000^{* * *}$ & $(0.000)$ \\
\hline \multicolumn{9}{|l|}{ Subjective dimension } \\
\hline \multicolumn{9}{|l|}{$\begin{array}{l}\text { Perceived Regional Economy } \\
\text { (ref. Better) }\end{array}$} \\
\hline About the same & & & & & $-0.500^{* * *}$ & $(0.076)$ & $-0.443^{* * *}$ & $(0.072)$ \\
\hline Worse & & & & & $-0.984^{* * *}$ & $(0.073)$ & $-0.888^{* * *}$ & $(0.070)$ \\
\hline \multicolumn{9}{|c|}{ Individual level indicators (Other explanations) } \\
\hline Awareness & & & & & & & $0.303^{* * *}$ & $(0.063)$ \\
\hline $\begin{array}{l}\text { Voted in EU parliamentary } \\
\text { elections? (ref. Neither) }\end{array}$ & & & & & & & & \\
\hline 1 & & & & & & & $0.240^{* *}$ & $(0.091)$ \\
\hline 2 & & & & & & & $0.495^{* * *}$ & $(0.062)$ \\
\hline $\begin{array}{l}\text { Effectiveness (ref. Very } \\
\text { effective ) }\end{array}$ & & & & & & & & \\
\hline Somewhat effective & & & & & & & $-0.398^{* * *}$ & $(0.080)$ \\
\hline Not so effective & & & & & & & $-1.071^{* * *}$ & $(0.102)$ \\
\hline Intercept & $0.456^{* * *}$ & $(0.071)$ & $-2.193^{* * *}$ & $(0.452)$ & $-2.897^{* * *}$ & $(0.412)$ & $-2.342^{* * *}$ & $(0.433)$ \\
\hline Variance (level 2) & 0.421 & & 0.164 & & 0.092 & & 0.082 & \\
\hline $\mathrm{N}$ & 15625 & & 15521 & & 15436 & & 15087 & \\
\hline Log Likelihood & -9947.678 & & -9794.352 & & -9173.390 & & -8656.698 & \\
\hline ICC & 0.114 & & 0.048 & & 0.03 & & 0.02 & \\
\hline chi2 & & & 243.341 & & 1091.121 & & 1503.332 & \\
\hline AIC & 19899.356 & & 19608.704 & & 18398.781 & & 17375.396 & \\
\hline $\mathrm{BIC}$ & 19914.670 & & 19685.203 & & 18597.536 & & 17611.665 & \\
\hline
\end{tabular}

Note: Coefficients are presented for the comparison between supporting for EU integration and not support. Standard errors in parentheses. ${ }^{*} p<0.05,{ }^{* *} p<0.01,{ }^{* * *} p<0.001$ 
Table 2. Mixed effect model with random effect at regional level for identification with Europe

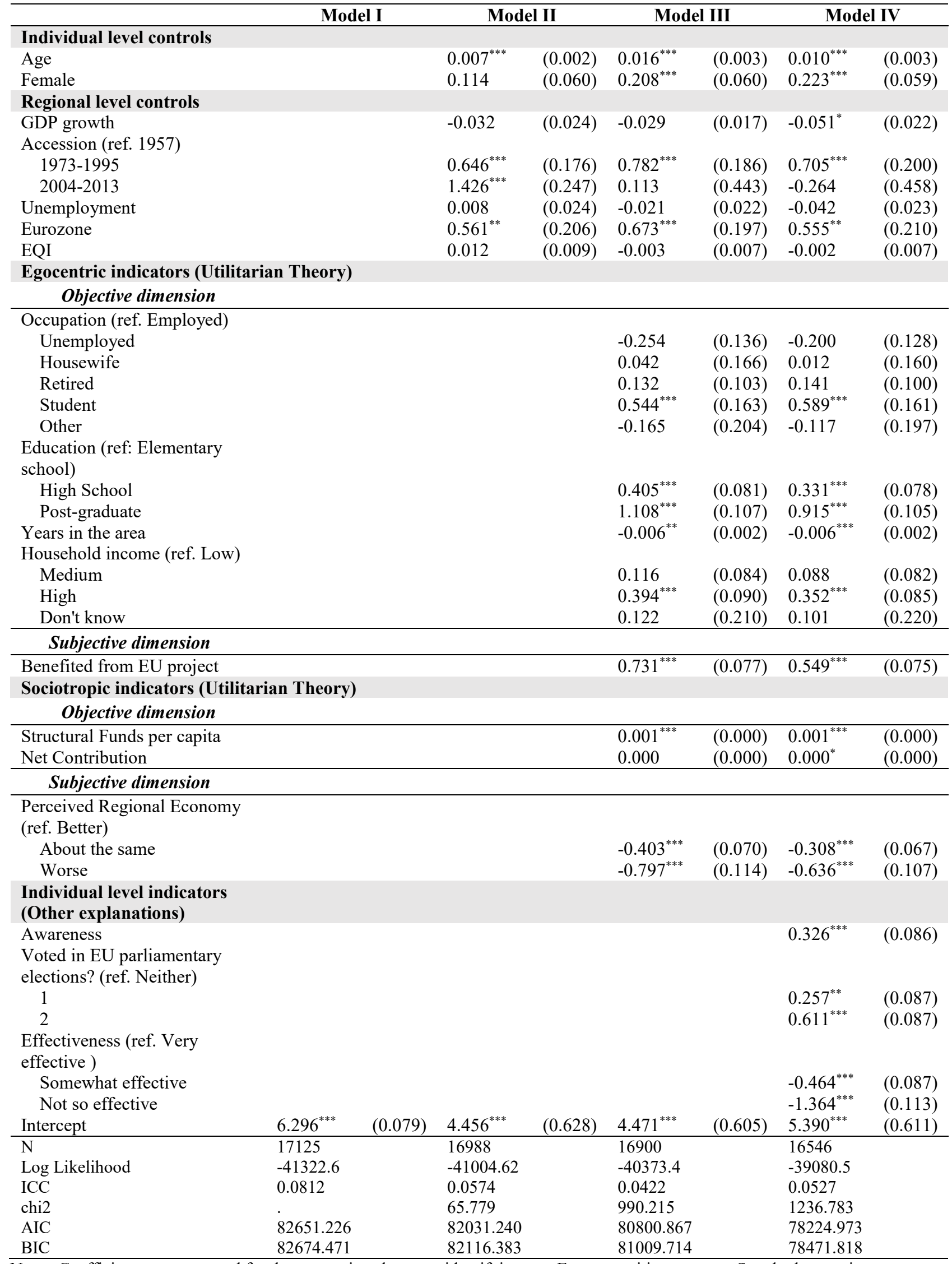

Note: Coefficients are presented for the comparison between identifying as a European citizens or not. Standard errors in parentheses. ${ }^{*} p<0.05,{ }^{* *} p<0.01,{ }^{* * *} p<0.001$ 
